\title{
Do espanto ao questionamento
}

\author{
Etienne Samain ${ }^{1}$
}

1 Professor titular aposentado do Instituto de Artes da Unicamp, atuando no programa de Pós-Graduação em Multimeios, onde tem orientado pesquisas de mestrado e doutorado com forte presença experimental das imagens. etienne.samain@gmail.com. 


\section{Resumo}

Palavras-chave

A partir de dois ensaios, intitulados "Quelle émotion! Quelle émotion?" e "Uma foto familiar: aprisco de emoções e pensamentos [anotações delirantes sobre (a)sombrografia]", assinados respectivamente por Georges Didi-Huberman e Eduardo Peñuela Cañizal, o artigo desenvolve uma reflexão sobre a história das artes visuais, a natureza das imagens, os modos de interpretá-las e a busca das emoções humanas em seus modos expressivos e artísticos. Ao fazê-lo, convida o leitor a ficar atento ao que cada um desses autores diz dos "gestos", do trabalho do "inconsciente" e da "imaginação", das dimensões - heurística e poética dos "arquivos da memória" humana.

Eduardo Peñuela, homenagem, memória, imagem.

\section{Abstract}

The present article reports on two theoretical essays, "Quelle émotion! Quelle émotion?", by Georges Didi-Huberman and "Uma foto familiar: aprisco de emoções e pensamentos [anotações delirantes sobre (a) sombrografia]" / "A familiar photo: unfolding emotions and thoughts [delusional notes on shadowgraphy], by Eduardo Peñuela Cañizal. It then reflects on the history of the visual arts, the nature of images, the ways we interpret them and the search for human emotions in their expressive and artistic forms. By doing that, we invite the reader to attempt to what each one of the mentioned authors has to say about "gestures", about the work of the "unconscious", about "imagination" and about the dimensions - heuristic and poetic - of the human "files of memory".

\section{Keywords}

Eduardo Peñuela, tribute, remembrance, image. 


\section{Aconteceu numa segunda-feira da semana santa}

Pensava escrever a Eduardo Peñuela a quem tinha enviado, três semanas mais cedo, da Bélgica, um pequeno livro.

Queria saber se tinha recebido o envelope de papel kraft e, colados no lado superior direito, três belos selos comemorativos do surrealismo, três imagens viajantes capazes de atravessar as fronteiras do tempo.

Soube, nesta manhã do dia 14 de abril de 2014, que não teria mais a resposta. O amigo tinha saído para uma longa viagem. Recebi, mudo, essa notícia. Uma grande emoção.

$$
* * *
$$

O pequeno livro de que acabei de falar é um opúsculo de 90 páginas, publicado em outubro de 2013, numa coleção intitulada "Les petites conférences".

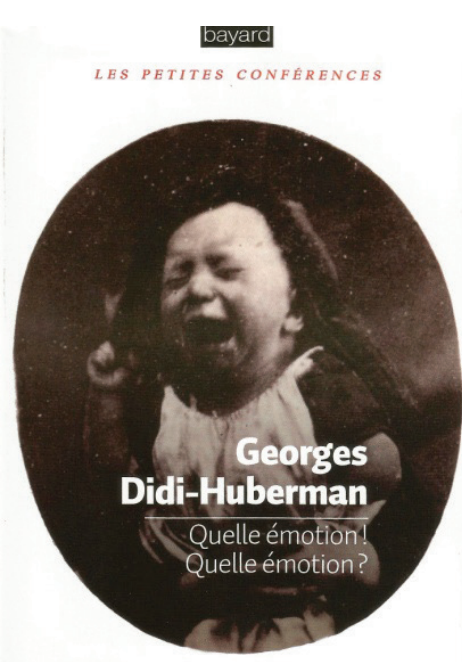

Figura 1: Capa do livro Quelle émotion! Quelle émotion?
Pequenas conferências que uma diretora de teatro, Gilberte Tsaï - inspirando-se nas conferências redigidas por Walter Benjamin entre 1929 e 1932 para o rádio alemão e destinadas à juventude - organiza a cada ano, em Montreuil (França), para crianças a partir de 10 anos e para os que as acompanham. Um único imperativo que é também a regra do jogo: os oradores convidados devem efetivamente se dirigir às crianças e fazê-lo fora dos lugares comuns. O convidado da conferência do dia 13 abril de 2013 foi Georges Didi-Huberman e o que disse foi transcrito sob o título Que emoção! Que emoção?². 
Li esse ensaio ao longo de um único dia. À noite, tínhamos a guarda de uma criancinha. Olhando para ela, me informei de sua idade. Ia fazer quatro meses. Algo me surpreendeu. Uma lembrança, uma memória: meus irmãos gêmeos, Yvonne e Michel, morriam juntos, numa mesma manhã, de pneumonia. Tinham quatro meses. Nunca vi seus rostos. Foi num 4 de abril de 1941.

Um arrepio silencioso, um soluço, outra emoção.

Eduardo Peñuela me ofereceu, dois anos atrás, um denso artigo que ele prezava muito. Reli várias vezes esse trabalho de análise de "Uma foto familiar: aprisco de emoções e pensamentos [anotações delirantes sobre (a) sombrografia]"3, no qual, logo de início, o autor nos dava essa informaçãochave: "Eu não tinha nascido ainda, mas aí estão as figuras de meus pais e meus irmãos".

Coloco esses dois trabalhos lado a lado. Abro-os novamente com o único desejo de saber melhor e de partilhar duas propostas metodológicas e dois percursos em torno da questão das emoções humanas. São viagens singulares e complementares. 


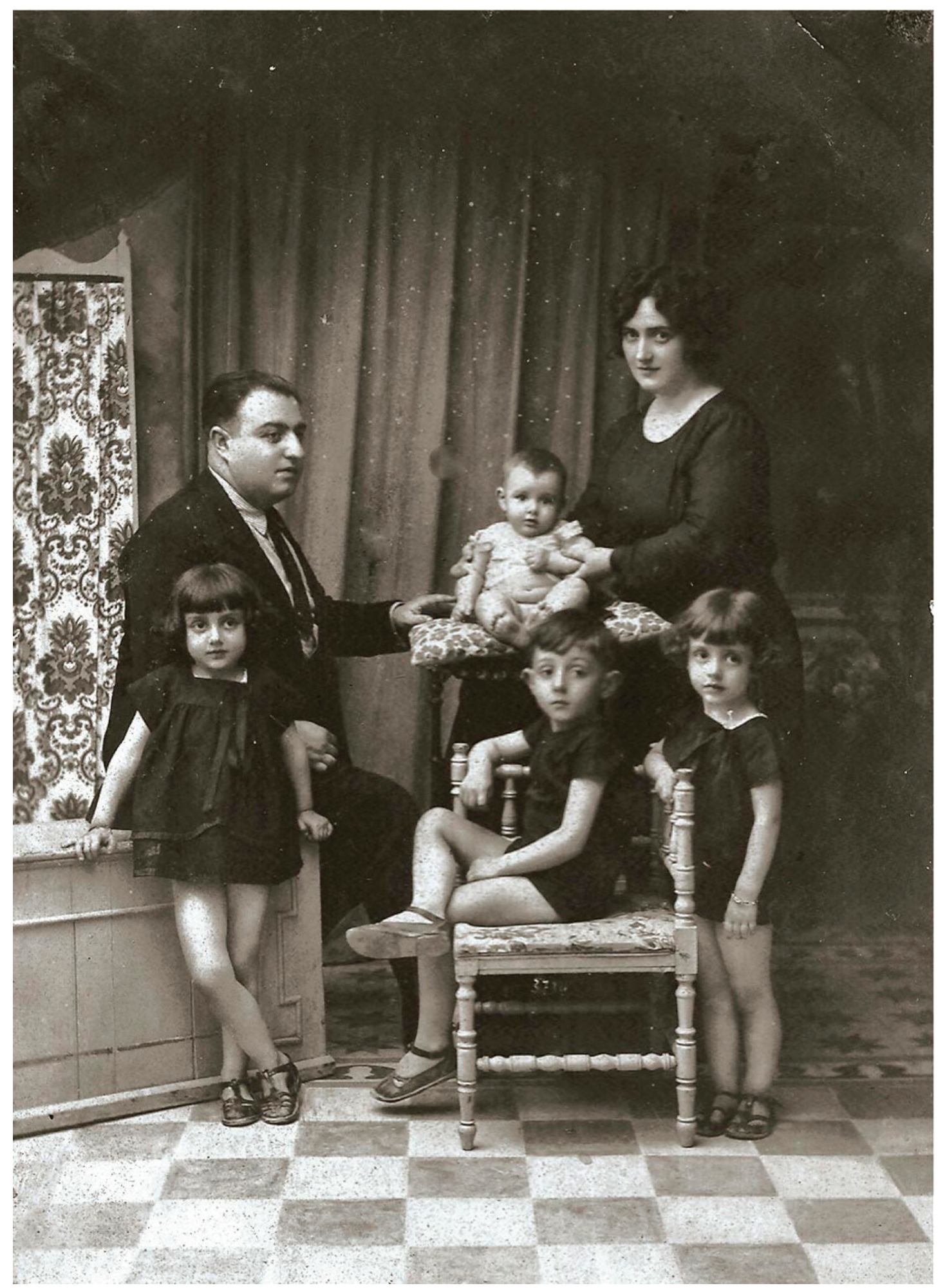

Figura 2: Família, 1929 


\title{
Uma dupla proposta metodológica
}

\author{
Peñuela é claro nos seus propósitos:
}

Confesso que a escolha desta fotografia não foi guiada exclusivamente pelo afetivo. Ela, sem dúvida, me comove e me injeta um efeito emocional confortador, pois, enquanto objeto de análise, mesmo tentando assumir um necessário distanciamento, mantenho com ela, para usar um termo de Júlio Cabrera, uma relação logopática sem a qual não conseguiria atinar com o que seus componentes imagéticos querem me dizer ou com o que eu pretendo que eles me digam. [...] É visceral minha necessidade de acariciar a pele expressiva dos significantes e participar, se possível, do diálogo que os referentes sussurram atrás da opacidade dessa cortina epidérmica. [...] Não se trata simplesmente de acalmar meu desejo de regressar a um passado vendo na foto uma relíquia dos tempos idos. Trata-se, isso sim, de averiguar mediante a leitura dos sinais aí congregados, os efeitos de sentido que nesta composição familiar ainda sobrevivem nas camadas expressivas em que se manifestam ou nas emanações provenientes da "caixa preta" psíquica (PEÑUELA CAÑIZAL, 2012, p. 111-112, passim).

Didi-Huberman partirá da imagem de uma criança que chora (fotografia de Oscar Gustave Rejlander encomendada por Charles Darwin para sua obra $A$ expressão das emoções no homem e nos animais, 1872) e iniciará seu livreto escrevendo: "Nascemos chorando. Ninguém se lembra, mas que enorme emoção deve ter sido o fato de nascer, de entrar no mundo". Logo, prosseguirá explicando o título repetitivo de seu ensaio.

O ponto de exclamação (Que emoção!) responde ao primeiro de todos os gestos filosóficos, que é de se admirar diante de uma coisa, um ser, uma experiência $[. .$.$] mas esse primeiro gesto de admiração não seria$ filosófico até o final se não se prolongasse numa questão levantada: que emoção? Ponto de interrogação que poderia muito facilmente se transformar em uma série sem fim de pontos de interrogação: o que entender por "emoção"? Que tipo de emoção? E por que a emoção? Por quais razões (o plural é importante, pois nunca se tem uma só razão para explicar as coisas de nossa vida)? Para que, em vista de que? E como, sim como? Como nasce uma emoção? Como se desenvolve? Desaparece? Recomeça? Etc. etc." (DIDI-HUBERMAN, 2013, p. 11-13, passim). 


\section{Dois percursos singulares}

Na fotografia acima reproduzida, Peñuela ficará atraído primeiro pelo "olhar" de seus irmãos que, embora "domesticado", não chega a esconder um "sentimento de assombro, indício do que significava então enfrentar uma câmera" (PEÑUELA CAÑIZAL, 2012, p. 110-111). Observará, logo também, a disposição das mãos de seus pais: "O dedo paternal que aponta na direção do filho menor", gesto de proteção reiterado e acentuado "pelas mãos maternas ao segurar com delicada firmeza o bebê". Enfim, realçará a disposição e o arranjo das "pessoas fotografadas formando uma configuração geométrica em que as tríades aludem a um pensamento simbólico" (PEÑUELA CAÑIZAL, 2012, p. 111): [...] "meus irmãos e meu pai permanecem sentados. Minhas irmãs e minha mãe erguidas, como se nelas o desenvolvimento fosse algo inerente à feminilidade" (PEÑUELA CAÑIZAL, 2012, p. 119).

Essa "peripateia gestual" (PEÑUELA CAÑIZAL, 2012, p. 115) fará com que Peñuela se interessasse pelas posturas de seus irmãos, bem como evocasse com precisão o destino de um mobiliário de um ateliê de fotografia do final dos anos 1920: tanto "cena de teatro improvisado no meio de um armazém de acessórios [...] quanto habitáculo de pose que se situa na fronteira de dois mundos emparedados: a sala de recepção, de um lado e, do outro, o laboratório propriamente dito" (PEÑUELA CAÑIZAL, 2012, p. 117).

Apontará para uma cadeira que ganhou suas simpatias. "Sobre ela meu irmão mais velho ensaia os gestos de uma pose previamente encenada e minha irmã menor camufla, num dos apoios de braço, uma atitude tradutora do tamanho de sua timidez" (PEÑUELA CAÑIZAL, 2012, p. 118).

Passará da cadeira ao baú "em que meu pai está sentado e sobre o qual minha irmã mais velha apoia as mãos com firmeza como se desejasse evitar que dessa espécie de arca fugisse algum segredo". E prossegue: "Na linha vertical, por trás da cadeira, vislumbro mais um componente da mobília do habitáculo da pose: há, na penumbra, uma cômoda em que meu irmão menor está sentado, 
mas firmemente protegido pelas cautelas da minha mãe e pelo aconchego de uma almofada" (PEÑUELA CAÑIZAL, 2012, p. 118).

Essa gestualidade envolvente da mãe e a aconchegante brandura da almofada usada com assento determinarão, daqui para frente, o que o autor designará como o "receptáculo fofo", isto é, esse "casulo intrauterino" (PEÑUELA CAÑIZAL, 2012, p. 122) onde se desenvolve o embrião humano que, nada mais, nada menos, evoca e remete ao que será, quatro anos depois, sua própria experiência de entrar na existência.

Partindo precisamente da experiência (e da imagem) de uma criança que nasce chorando, Georges Didi-Huberman iniciará uma outra viagem para adentrar, também, a questão das emoções humanas e refleti-las conosco à luz da filosofia e da história das artes visuais, já que as imagens são "espécies de cristais dentro dos quais se concentram muitas coisas, e em especial esses gestos muito antigos, essas expressões coletivas que atravessam a história" (DIDI-HUBERMAN, 2013, p. 43).

Muitos filósofos clássicos (de Platão até Kant) tiveram tendência a "considerar a emoção como sendo uma fraqueza, um defeito, uma impotência. A emoção se oporia de um lado à razão e, de outro, à ação":

\footnotetext{
A emoção seria deste modo um impasse: impasse da linguagem (quando, emocionado, permaneço mudo não conseguindo mais achar minhas palavras); impasse do pensamento (quando, emocionado, perco todos os meus meios); impasse do ato (quando, emocionado, permaneço de braços pendentes, incapaz de me mexer como se uma serpente invisível me imobilizasse). Ora, um impasse, é quando a gente não passa: é uma noção negativa (DIDI-HUBERMAN, 2013, p. 25-27, passim).
}

Felizmente, Hegel dirá mais tarde que "sem impasses, a gente não saberia sequer o que é uma passagem. Nietzsche, por sua vez, chamará a emoção de 'fonte originária' da qual a arte ou a poesia sabem nos mostrar a força e a importância para toda nossa vida" (DIDI-HUBERMAN, 2013: 29). Com o autor da Gaia Ciência "a 
vida sensível será descrita [daqui para frente] na sua energia, inclusive passional, e não apenas prescrita nos seus deveres de razão e de ação" (DIDI-HUBERMAN, 2013, p. 30). Henri Bergson, enfim, considerará "as emoções como gestos ativos [...], gestos que dizem com clareza, aliás, o que a própria palavra significa: será que uma emoção não é uma e-moção, isto é uma moção, um movimento que consiste a nos colocar fora de (e-. ex), fora de nós mesmos? Mas se a emoção é um movimento, ela é, consequentemente, uma ação" (DIDI-HUBERMAN, 2013, p. 31).

Georges Didi-Huberman assim chega a um momento chave de sua exposição, quando lembra a curta frase de Gilles Deleuze: "A emoção não diz eu" e a exemplifica através de referências ao historiador arte (Aby Warburg) e a cineastas (Pasolini e Eisenstein).

\begin{abstract}
A emoção não diz eu: primeiro porque, dentro de mim, o inconsciente é muito maior, mais profundo, mais transversal que meu pobre pequeno "eu". Depois porque em torno do eu, a sociedade, a comunidade dos homens é, ela também, muito maior, mais profunda, mais transversal que cada pequeno "eu" individual (DIDI-HUBERMAN, 2013, p. 37).

As emoções, já que são moções, movimentos, comoções, são também transformações daqueles ou daquelas que são emocionados. [...] É até através das emoções que se pode, eventualmente, transformar nosso mundo, com a condição evidentemente de que elas se transformem em pensamentos e em ações (DIDI-HUBERMAN, 2013, p. 49).
\end{abstract}

Didi-Huberman oferece, nesse momento, ao seu leitor dez fotogramas do filme de Sergei Eisenstein, O encouraçado Potemkin (1925), quando a tristeza do luto (ante o cadáver de um marinheiro assassinado) transforma-se em cólera surda, depois em discursos e cantos revolucionários, quando passa da exaltação e se transforma em ato revolucionário. "Como se o povo em lágrimas se tornasse, sob nossos olhos, um povo em armas"4 (DIDI-HUBERMAN, 2013, p. 48-54). (O olho da história), uma clara referência a Georges Bataille e ao seu inquietante livro História do olho. Os títulos dos tomos já publicados são significativos: Vol.1: Quando as imagens tomam posição (2009). Vol.2: Remontagens do tempo sofrido (2010). Vol.3: Atlas ou a Gaia ciência inquieta (2011) (traduzido para o português: 2013). Vol.4: Povos expostos, povos figurantes (2012). 


\section{Para falar ainda de emoções}

Para se ter uma ideia das variedades e nuanças das emoções, bastaria remeter a essas preciosas figurações simbólicas, esses ícones que são os emoticons que pontuam a comunicação humana nas redes sociais da web. No entanto, fala-se pouco delas. Não têm peso, nem consistência, dirão uns; não são sérias e confiáveis, dirão outros.

As emoções, é verdade, não sabem falar. Estarão sempre à procura de suas próprias palavras. Elas são signos, gestos, atitudes, expressões. As emoções, no que Ihes diz respeito, não procuram uma explicação. Elas se dão e não pertencem à ordem da razão. Positivas ou negativas, expressivas ou contidas, elas fazem parte e declinam-se no DNA existencial e social de cada indivíduo. Elas são da ordem do vivido.

Fugazes, passageiras, nómades, as emoções - das mais simples às mais fortes - surgem de repente, sem que se possa contê-las. Nascem, nos desorientam, desaparecem como o voo de uma borboleta.

Ora silenciosas e discretas, ora convulsivas e exuberantes, as emoções são também necessidades inscritas no fundo de nossa experiência vivida. Elas são ao mesmo tempo memórias, provocações e questionamentos.

Volto aos trabalhos de Eduardo Peñuela e de Georges Didi-Huberman. São duas tentativas, duas aproximações em torno de uma mesma procura: o que dizer das emoções humanas? Como pensá-las?

Ambos os autores partem de uma imagem: uma "foto familiar: as figuras de meus pais e meus irmãos", de um lado; a fotografia de uma "criança que chora", do outro.

Ambos assinalam a direção dada ao seu ensaio. Peñuela escreverá: "Obedeço ao desígnio de me aproximar da vida dos signos na sociedade, buscando suas origens ou, na esteira de Bakhtin, vivendo o deslumbramento de 
sua constante ressurreição" (PEÑUELA CAÑIZAL, 2012, p. 111). Didi-Huberman confiará: "Queria me dirigir à possibilidade de que a emoção transforme algo de maneira ativa. [...] Minha conferência era o comentário dessa frase: 'A emoção não diz eu'"' (DIDI-HUBERMAN, 2013, p. 71).

Dois itinerários e duas viagens. De um lado, a viagem de um semiólogo da visualidade que mergulha numa única imagem (uma fotografia querida): imersão e descida abissal nas camadas expressivas dos signos e das paixões humanas. Do outro, a viagem de um historiador da arte que explora os horizontes de imagens múltiplas (fotografias e fotogramas) e que, como filósofo, redescobre nas emoções seus "valores de uso", isto é, suas potencialidades de transformação social.

Não faltam "emoções" no mundo nosso, mas elas são tantas e a tal ponto banalizadas que acabarão não nos tocando mais. Ao reler esses dois textos, convido o leitor a ficar atento ao que cada um desses autores diz dos "gestos", do trabalho do "inconsciente" e da "imaginação", das dimensões - heurística e poética - dos "arquivos da memória" humana.

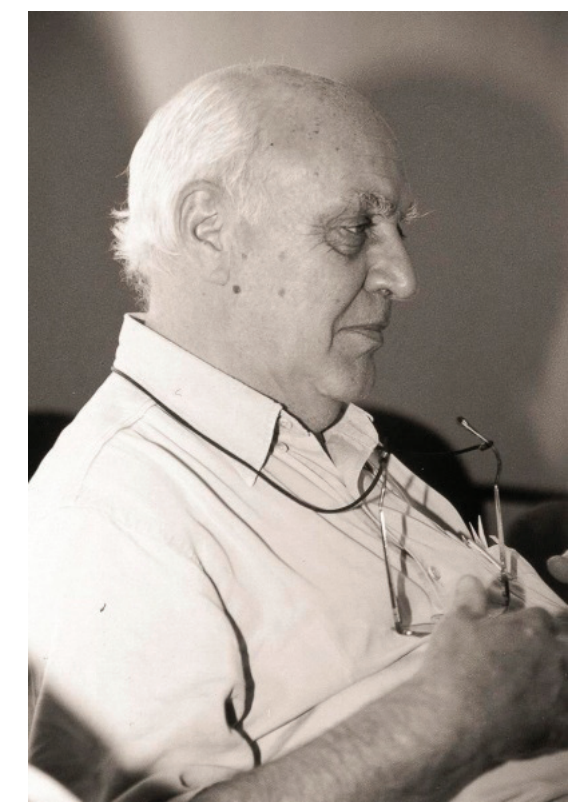

Figura 3: O amigo, set. 2005

Que tomem sobretudo o tempo de se deixar tocar e questionar pelo olhar do amigo. 


\section{Referências}

DIDI-HUBERMAN, G. Quelle émotion! Quelle émotion? Paris: Bayard, 2013, 90 p. II (Les petites conférences).

PEÑUELA CAÑIZAL, E. Uma foto familiar: aprisco de emoções e pensamentos [anotações delirantes sobre (a)sombrografia]. In: SAMAIN, E. (org.). Como pensam as imagens. Campinas, Editora da Unicamp, 2012, p. 107-132. 